IJLRES - International Journal on Language, Research and Education Studies

ISSN: $2580-6777(\mathrm{p}) ; 2580-6785$ (e)

DOI: $10.30575 / 2017-2018010409$

Vol. 2, No. 1, 2018

Page: 116 - 128

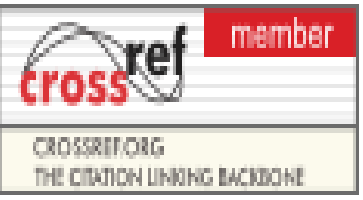

\title{
THE MECHANISM OF LEGAL MARRIAGE PREVENTION AND CANCELLATION BASED ON ISLAMIC LAW COMPILATION
}

\author{
Zakiah \\ University of North Sumatra, Indonesia \\ umizakiahrangkuti8@gmail.com
}

\begin{abstract}
This study aims to find out the legal mechanisms of marriage prevention and cancellation as well as the position of the children in cases of cancelled or prevented marriage. The method used in the writing of this journal is a qualitative method with data collection techniques of literature research which is then analyzed within the technique of descriptive analysis. The results of the study indicate that the legal provisions of the mechanism of prevention and cancellation of marriage can be done by applying for the prevention or the cancellation of a marriage to the Court / Religious Court in which the husband or wife resides or where the marriage takes place. The procedure for filing a marriage cancellation is done in accordance with the procedure for filing a divorce suit. The provisions of article 76 of the compilation of Islamic law has guaranteed a legal protection of the child from a cancelled marriage. The compilation of Islamic law also confirms that the cancellation of a marriage will not break the legal relationship between the child and his or her parents. Based on the results of the research, it is fund out that the government needs to pay attention and improve the weaknesses and the lack of regulation in terms of the prevention and the cancellation of marriages.
\end{abstract}

Keywords: Mechanism, Prevention and Cancellation, Marriage.

\section{INTRODUCTION}

A marriage is an important event in human life because a marriage is not limited to the relationship and affairs of a husband and a wife but also concerns with the relationship and affairs of a family and a society. In general, a marriage is regarded as sacred and hence, every religion tends to connect marriage methods with religious sanctions.

A marriage is also a way that God chooses for people to continue their offspring and preserve their lives after each considered party is ready to play their roles in realizing the purpose of a marriage. In a marriage, there is a rule given by God that aims to elevate the humankind above His other creatures. With the marriage, the relationship 
between men and women occurs respectably. The marriage bond is the most sacred and most solid tie called the Mitsaqon Ghalizhan (a firm covenant). ${ }^{1}$

Principally, the purpose of a marriage is to form an eternally happy family. This is affirmed in the marriage law No. 1 of 1974 which states that a marriage is an inner and outer relationship between a man and a woman as a husband and a wife in forming a happy and an eternal family (household) based on the divinity of the One Supreme. ${ }^{2}$ Sayyid Sabiq writes in his Sunna Fiqh book: "Marriage is a way that God chooses for humankind to multiply, reproduce and preserve their generations and live after each party in a marriage is ready to perform their positive roles in realizing the goal of a marriage". 3

God does not want to make men like other creatures which live freely following their instincts and relate to each other anarchically without rules. In order to safeguard human dignity, Allah creates the law that arranges the relationship between men and women in a respectable manners and is based on mutual acceptance with a ceremony of ijab and qabul as a symbol of a sense of merriment with the presence of witnesses who testify that the man and the woman performing the ceremony have been tied together. A marriage under the Islamic law will at least:

1. Create the relationship between men and women honorably in a state of mutual acceptance

2. Give the most sexually correct way to satisfy each other as a healthy human instinct, maintain good offspring and protect women from men's oppressions

3. Establish a husband and a wife associations in the shadow of maternal and paternal instincts, give birth to good descendants as the next generation to sustain the caliphate mission

4. Provide an orderly and safe environment in social life. ${ }^{4}$

\footnotetext{
${ }^{1}$ Sayyid Sabiq, Fiqih Sunah jld 8, (Bandung, Al-Ma'arif, 1990), p. 7

${ }^{2}$ Undang-undang Perkawinan Republik Indonesia no. 1 Tahun 1974, Arkola, Surabaya, p. 5

${ }^{3}$ Mohammad Thalib, (Trans) Sayyid Sabiq, Fikih Sunnah Jilid 6 Cet 15 (Bandung : PT. Alma'arif, 1980), p. 72

${ }^{4}$ H. M. Zuffran Sabrie, Analisa Hukum Islam Tentang Anak Luar Nikah. (Jakarta: Departemen Agama RI, 1998), p. 7-8.
} 
In Islamic law, children occupy a very important place in a family. As God's given trust, parents have responsibilities to nurture, educate and meet the needs of children from their childhood to adulthood. Every couple would want normal, healthy, and pious children. Good offspring is generated by the efforts and good deeds of their parents. From a medical point of view, a man and a woman who still have a blood ties with each other (mahram) are not allowed to marry. One of the causes of ethnic destruction is the very small marital relations within the scope of a particular group of family because that is proven to be very damaging genealogically and weakening the offspring's quality. ${ }^{5}$

In the Qur'an An-Nisa verse 23, Allah explains about unlawful women to be married with. The meaning of the verse is:

"Prohibited to you [for marriage] are your mothers, your daughters, your sisters, your father's sisters, your mother's sisters, your brother's daughters, your sister's daughters, your [milk] mothers who nursed you, your sisters through nursing, your wives' mothers, and your stepdaughters under your guardianship [born] of your wives unto whom you have gone in. But if you have not gone in unto them, there is no sin upon you. And [also prohibited are] the wives of your sons who are from your [own] loins, and that you take [in marriage] two sisters simultaneously, except for what has already occurred. Indeed, Allah is ever forgiving and Merciful."

God's provision in His words above is a non-negotiable law. Therefore, the marriage that occurs between a man and a woman as mentioned in the above paragraph is deemed damaged (fasid) or void. The cancellation of a marriage means that it is illegitimate because one or all of its terms are not fulfilled, or any other causes prohibited or forbidden by the religion. ${ }^{6}$

The automatic breakdown of a marriage that is due to the violation of Allah's provisions in the above verse is called Fasakh. Fasakh is one form of divorce that does not have iddah because both cannot reconcile. Fasakh because of the things that happen later or because of conditions that are not fulfilled cut the marriage ties instantly. This is called the ba' in talak. ${ }^{7}$

\footnotetext{
${ }^{5}$ Syaikh Hasan Ayyub, "Fiqhul Usroh Al-Muslimah", diterjemahkan M. Abdul Ghoffar, FikihKeluarga (Cet. I; Jakarta: Pustaka Al-Kautsar, 1999),p. 15

${ }^{6}$ Abd. Rahman Ghazaly, Fiqh Munakahat Seri Buku Daras (Cet. II; Jakarta: Kencana, 2006), p.141.

${ }^{7}$ Ibid., p. 143.
} 


\section{The Mechanism of Legal Marriage Prevention and Cancellation Based on Islamic Law \\ Compilation}

DOI: 10.30575/2017/IJLRES-2018010409

There are many possibilities that might lead to incestuous marriages between fellow mahram or a marriage that is carried out without the fulfillment of the conditions of the marriage that have been established. An ignorance and feelings of love may be a contributing factor. An ignorance that the groom or the bride is a mahram to the other without any other factors that are considered to cancel the marriage can still be regarded as an understandable mistake. The law of sin cannot be imposed because of this ignorance. However, if feelings of love are used as an excuse to keep this type of marriage, this is a big mistake.

Chapter IV about the prohibition of a marriage in the compilation of Islamic law also provides a rule regarding women who are forbidden to marry due to the familial connection, kinship relation, and wet nurse relation. A man should not marry a woman who is still bound by a marriage with another man, is still in the iddah period, or the woman, for instance, is not a Muslim. ${ }^{8}$ Things that can lead to the cancellation of a marriage may include, but are not limited to, the non-fulfillment of one or all of the legal requirements of a marriage such as marrying someone who has blood relations to the party wishing to marry her or him like siblings or half-siblings, for instance.

In general, there are things that distinguish a marriage prevention or cancellation in law number 1 of 1974 and that of the compilation of Islamic law. In the 1974 law chapter III on the prevention of marriage and chapter IV on the cancellation of marriage, it is explained that a marriage can be prevented if there are parties who do not meet the requirements of a marriage. Furthermore, Article 16 states that the officer appointed to handle the marriage shall stop the marriage if the provisions of Article 7 paragraph (1), Article 8, Article 9, Article 10 and Article 12 of this Law are not fulfilled. Furthermore, in accordance with Article 19, which the marriage shall not take place if the prevention suit is not revoked.

Furthermore, the article 70 of the compilation of Islamic law explains that a marriage is void if:

a) A man already has four wives even if one of the four wives is in the iddah period from a raj'i talak given by him.

b) A man marries a former wife whom he delivered a li'an to.

c) A man married his ex-wife who had been divorced by three divorces by him.

\footnotetext{
${ }^{8}$ The instructions of the President of the Republic of Indonesia number 1 in 1991
} 
d) The marriage is done by two people who have a blood or a wet nurse relation.

The article 71 compilation of Islamic law also sets forth the cancellation of a marriage because:

a) A husband commits polygamy without the permission of the Religious Courts.

b) The married woman is known to still be the wife of another man.

c) The married woman is still in the iddah period.

d) The marriage violates the marriage age limits set forth in Article 7 of 1974 Law no. 1.

e) The marriage is held without a guardian or performed by an unauthorized trustee.

f) The marriage is conducted by force.

Therefore, based on the above description, the assessment of the marriage prevention and cancellation mechanisms is required. This is outlined in this thesis research entitled: "The Mechanism of Marriage Legal Prevention and Cancellation Based on the Islamic Law Compilation".

\section{LITERATURE REVIEW}

\section{Definition of the Marriage Prevention and Cancellation}

The prevention of a marriage aims to avoid the occurrence of a marriage that are prohibited by the Islamic law and the legislation.

The prevention of a marriage can only be done if the prospective husband or wife does not meet the requirements to establish a marriage according to the Islamic law and the legislation.

The Islamic law recognizes the prohibition and the cancellation of a marriage. The fiqh term for people who should not be married is mahram. In society, the term "muhrim" is often associated with the husband. A wife should not marry another man while is still bound in a marriage with her husband or is still in 'iddah period from raj' $i$ talak. In addition to that, the word "muhrim" is also used to refer to people who perform ihram. ${ }^{9}$

\footnotetext{
${ }^{9}$ Abdul Aziz Dahlan, Ensiklopedia Hukum Islam, jilid 3, (Jakarta : Ichtiar Baru Van Hoeve),
} p.1049 
A marriage that has fulfilled all the terms and the prescribed conditions is not necessarily legitimate because the marriage itself must be detached from all things that can hinder its legality. The marriage barrier is also called the ban on a marriage. The cancellation of a marriage or the breaking of marriage is also called fasakh. What is meant by cancelling a marriage is to cut the bond between a husband and a wife because of the conditions or the pillars are not met. Terminologically, fasakh means null and void whereas according to syar'i term, fasakh is the cancellation or the termination of a marriage ties based on the decision of the Qodhi ${ }^{10}$ or:

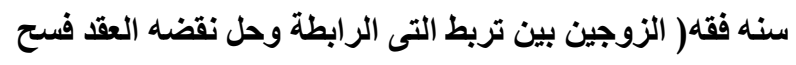

Faskhul Aqdhi is the cancellation of the bond (marriage) and the breaking of the relationship ties that binds husband and wife. ${ }^{11}$

Fasakh also means revoking or canceling. Djamil Latif argued that the meaning of fasakh refers to the power of a qodhi Islam in canceling a marriage at the request of the wife or the husband. ${ }^{12}$

\section{Potential Factors Leading to A Marriage Cancellation}

Amir Syarifuddin suggests that the prevention or the cancellation of a marriage can be practiced to marriages that falls into the following categories: ${ }^{13}$. First, the marriage that had previously been held did not meet the specified requirements, either in terms of the pillars or the conditions; or in a marriage, there are obstacles that do not justify the occurrence of the marriage. This is referred to as fasakh in Fiqh term. ${ }^{14}$. Second: the fasakh that occurs due to the fact that causes the marriage will cause damage to either the husband or the wife or both at once if continue, for instance. Fasakh in this form in fiqh is called khiyar fasakh.15

\footnotetext{
${ }^{10}$ M. Anwar, Dasar-Dasar hukum Islam dalam Menetapkan Keputusan di Pengadilan Agama (Bandung: CV. Diponegoro, 1991), p.73

${ }^{11}$ Sayyid Sabiq, Fiqh Sunnah VIII, Alih bahasa M. Tholib (Bandung : PT. Al-MA'arif, 1993), p.124

12 M. Djamil Latif, Aneka Hukum di Indonesia (Jakarta: Ghalia Indonesia,1982),p. 63

${ }^{13}$ Amir Syarifuddin, Hukum Perkawinan Islam Di Indonesia : Antara Fiqh Munakahah dan UUP (Jakarta: Kencana, 2007) cet II, p.243

${ }^{14}$ Ibid., p. 243

${ }^{15}$ Ibid, p. 244
} 
Fasakh which occurs either in the form of a violation of the marriage law or the existence of the obstacles that hinder the marriage to proceed, will treat the legal consequences. Particularly, due to the law resulted by the breaking of a marriage fasakh, a husband should not visit his ex-wife before the iddah period is completed because a divorce in the form of this fasakh falls into the ba'in sughro status. If the former husband and the ex-wife wish to continue their marriage, they have to do a new marriage contract, both in when the ex-wife undergoes the iddah or after the completion of the iddah period..$^{16}$

Fasakh can also occur due to the non-fulfillment of the conditions when the marriage ceremony takes place or because of other things that come later and might cancel the marital sustainability. ${ }^{17}$

a. Fasakh due to the unfulfilled conditions when the marriage occurs.

1. After the marriage ceremony, it turns out that the wife is the husband's sister.

2. The husband and the wife are still very young and the marriage is conducted by a person other than the husband's father or grandfather. Then, when the husband grow up, he was entitled to options to either continue his previous marriage or end it. This way is called khiyar baligh. If the husband choose to end the ties, this is called fasakh baligh.

b. Fasakh because of things that come after the contract.

1. If one of the husband's wife reneged or walk out of Islam and did not want to return at all, then the marriage is void because of the aapostasy that occurred later.

2. If the unbelieving husband converts to Islam, but the wife is still in disbelief, then the contract is void as well unless the wife is a scribe where the contract remains valid as it was originally because this is considered legitimate. ${ }^{18}$

The provisions of Law No. 1 of 1974 provide a review of the reasons underlying the cancellation of a marriage:

\footnotetext{
${ }^{16}$ Ibid., p. 253

17 Abd. Rahman Ghazaly, Fiqh Munakahah Seri Buku Daras (Jakarta : Kencana,tt), p. 142

18 Sayyid Sabiq, Fiqh Sunnah cet ke- 4 jilid II (Beirut : Dar Al- Fikr, 1983), p. 268
} 
1. Marriage is held under unlawful threat(s) (article 27 of Law No. 1/1974).

2. One party falsified his/her identity regarding status, age, name, or religion (Article 27 of Law No. 1/1974).

3. The husband/the wive who still have marital ties marry without the consent and the knowledge of the other (Article 24 of Law No. 1 Year 1974).4) The marriage is not in accordance with the terms of the marriage itself(Article 22 of the Marriage Law)

In line with the provisions of Law No. 1 of 1974 above, the Compilation of Islamic Law has also perfected the rules relating to the cancellation of a marriage into two categories, the marriage which is automatically null and void, and the one which can be canceled.

The marriage which is null and void by itself is a marriage committed by a husband when he is not entitled to anther marriage because he already has four wives, even if one of his four wives is in iddah from raj'i talak, someone marries his ex-wife whom he has delivered a li'an to, a man marries his ex-wife who had been sent three talaks, unless former wife has already married to another man who then divorced her again after that and has expired her iddah. ${ }^{19}$

Further more, the marriage between two people who have a blood relationship or a wetnurse relationship up to a certain degree that precludes marriage under Article 8 of Law no. 1 Year 1974 is: related in the bloodline straight downward or upward, related in the lateral lineage between the brothers, parent's brother(s) or sister(s), or grandparents, in-laws, stepchildren, and stepmother or stepfather, wetnurse mother, brother/sister, aunt or uncle, wife is siblings or aunts or nephews of his wife. ${ }^{20}$

A revocable marriage is a polygamous marriage committed by a husband without the permission of the Religious Court, or a marriage that has or will take place where the woman is still the lawful wife of another man or is still in the iddah of another husband, a marriage that violates the marriage age limit as set forth in Article 7 of Law 1 of 1974, a marriage that is held without guardians or exercised by unlawful guardians and forced marriages. ${ }^{21}$

\footnotetext{
${ }^{19}$ See chapter 70 of the Compilation of Islamic Law

${ }^{20}$ Ibid.,

${ }^{21}$ See chapter 71 Compilation of Islamic Law
} 
A husband or a wife may also apply for the cancellation of the marriage if the marriage is conducted under unlawful threat, or fraud or misconduct perceptions concerning the husband or the wife. The provision is void if the threats made by the husband or wife has ceased, or the guilty consciously aware of the situation and within six months after it, they still live as a husband and a wife. In this case, the other parties can not exercise their right to apply for cancellation of the marriage.22

The provisions of the Compilation of Islamic Law above illustrate that marriages are nullified by themselves because of a nasab relationship or because of the prohibition that causes the obstruction of the marriage of both sides permanently, while the uaborted marriage usually comes from the outside or due to the existence of a temporary ban at the time of the marriage.

\section{METHODOLOGY}

This is literature research with approach of exploring various sources of the mechanism of legal marriage prevention and cancellation based on Islamic law compilation theory related to problem discussed. The researcher conducted in-depth literature review in an attempt to find a suitable model in theory which can then be applied by the people to solve the problems the case faced by public in accordance with the study.

\section{FINDINGS AND DSICUSSION}

\section{The Marriage Prevention Procedures}

The Compilation of Islamic Law has provided a reference to the procedure for the prevention of a marriage. The parevention of a marriage can only be done if the prospective husband or wife does not meet the requirements to establish the marriage according to Islamic law and the legislation. The prevention of a marriage may be done by a husband or a wife by applying to the Religious Courts within his or her jurisdiction by notifying the Officer of the Registrar. In order to avoid any post-notification marriage, the marriage registry officer shall notify the prospective groom and bride of the marriage prevention request. ${ }^{23}$

\footnotetext{
${ }^{22}$ See chapter 72 of the Compilation of Islamic Law

${ }^{23}$ See chapter 62 Compilation of Islamic Law
} 
The prevention of a marriage can also be conducted by the family members in the line straight up and down, brothers, the guardian of the marriage himself or one of the guardians of the prospective bride and the parties concerned. A biological father as a guardian who has not performed his role as head of the family, for example, does not fail to get his rights to prevent a marriage to be performed by another marriage guardian..$^{24}$

The prevention of a marriage may also be done by a husband or a wife if one of them is still bound in a marriage relationship with someone else. Officials appointed to oversee the marriage shall be obliged to prevent that marriage becasue the marital conditions are not met.

The marriage certificate clerk is not allowed to establish or assist the marriage if he is aware of any violation of the provisions of Article 7 paragraph (1), Article 8, Article 9, Article 10 or Article 12 of Law No. 1 of 1974, although there is no suit of prevention of the marriage. 25

The prevention of a marriage may be revoked by withdrawing the prevention request at the Religious Courts or with the decision of the Religious courts Courts.4.1.2 The Marriage Cancellation Procedures The compilation of Islamic Law explains the procedure of the marriage cancellation. A marriage may be declared void after a Religious court's decision that has a permanent and valid legal force from the moment of marriage is issued.

Article 37 of Government Regulation No. 9 of 1975 on the Implementation of Law Number 1 Year 1974 concerning a marriage also affirms that the cancellation of a marriage can only be decided by the Court.

The cancellation of a marriage can be done by applying for the cancellation of a marriage to the Court/Religious Court within the husband's or wife's residency. ${ }^{26}$ The procedure for filing a marriage cancellation should be in accordance with the procedure for filing a divorce suit. The marriage cancellation lawsuit is filed by the

\footnotetext{
${ }^{24}$ See chapter 63 Compilation of Islamic Law

${ }^{25}$ See chapter 68 Compilation of Islamic Law

${ }^{26}$ See Article 25 of Law no. 1 Year 1974 \& Article 74 Compilation of Islamic Law
} 
competent authority or the husband's / the wife's attorney to the Court whose legal area covers the defendant's residence. 27

The petition for the cancellation of a marriage can only be done by families in straight line up and down from the side of the husband or the wife, husband or wife or the officials authorized to supervise the implementation of the marriage according to the Act. In addition, interested parties and those aware of any defects in the pillars and the requirements under the Islamic law and the Laws and Regulations may apply for the cancellation of the marriage as well. ${ }^{28}$

\section{The Status of Children from Cancelled or Prevented Marriage.}

By law, a child is considered valid if the child is born of a legal marriage. Legitimate marriage is a marriage that meets the terms of the conditions set forth in article 6 of the Marriage Act. Essentially, interrupted marriages, whether due to death, divorce or the annulment of the marriage, will bring legal consequences to the position of the husband and wife, the position of the child and the position of the common property or property acquired during the marriage.

A married couple whose marriage is cancelled will break the ties, but should not sever the legal relationship between the child themselves.

Article 28 of Law no. 1 of 1974 and article 75 of the Compilation of Islamic Law affirms that the cancellation of a marriage under a court decision does not apply to children born in the marriage.

The above provisions illustrate that a child is still entitled to full legal protection and recognition from the government and from his or her parents. The position of the child remains lawful even if the marriage of their parents is void because the child was born from a legitimate marriage before.

The Compilation of Islamic Law also states that the cancellation of a marriage will not break the legal relationship between the child and his or her parents. ${ }^{29}$ The above provisions provide the understanding that the child who was born after the court canceled the marriage of his or her parents, is still regarded as a legitimate child.

\footnotetext{
${ }^{27}$ See Article 38 (2) of Government Regulation No. 9 of 1975 on the Implementation of Law Number 1 Year 1974

${ }^{28}$ See chapter 73 Compilation of Islamic Law

${ }^{29}$ See chapter 76 of the Compilation of Islamic Law
} 
The legal implications of the nasab and the guardianship of the child can also be attributed to his father. The child can still inherit properties from his or her father or mother. The child would also have a familial relationship with the family of both sides of his or her parents.

\section{CONCLUSION}

Based on the description from the previous chapters, the following conclusions can be drawn:

1. The legal provisions of the mechanism for the prevention and the cancellation of a marriage can be done by applying for the prevention or cancellation of the marriage to the Court / Religious Court which occupies the husband's or wife's residence. The procedures for filing of a marriage cancellation should be in accordance with the procedures for filing a divorce suit.

2. The provisions of the Laws and Regulations as provided in article 76 of the Compilation of Islamic Laws have guaranteed legal protections for children from a cancelled marriage. The Compilation of Islamic Law also states that the cancellation of a marriage will not break the legal relationship between a child and his or her parents.

\section{BIBILIOGRAPHY}

Abdurrahman. Kompilasi Hukum Islam, Jakarta : Akademika Pressindo, 1992

Al Jaziri, Abdu Ar Rahman. Kitab al Fiqih 'Ala Al Ma'zahib Al Arba'ah, Beirut: Dar Al Fikr, 1969

Al-Qurtuby, Ibn Rusyd, Al-Andalusi. Bidayah al-Mujtahid, juz II, Beirut, Libanon: Dar alKutub al-Ilmiyah, t.t.

Al-Jaziry, Abdurrahman. Kitab al-Figh 'ala al-Madzahib al-Arba'ah, Beirut: Maktabah alTijariyah Kubra, Juz IV, t.th.

Abidin, Slamet, Aminudin. Fiqih Munakahat, Bandung: Pustaka Setia, 1999

Abu Al Ghifari. Pernikahan Dini Dilema Generasi Extravaganza, Bandung: Mujahid Press, 2002 


\section{Zakiah}

Bakri, A Rahman, Sukadja, Ahmadi. Hukum Perkawinan Menurut Islam, Undang-undang Perkawinan dan Hukum Perdata/BW, Jakarta: Hidakarya Agung, 1981

Departemen P dan K. Kamus Besar Indonesia, cet. 3, Jakarta : Balai Pustaka, 1990

Daly, Peunoh. Hukum Perkawinan Islam: Suatu Studi Perbandingan dalam Kalangan Ahli Sunnah dan Negara-negara Islam, cet. I, Yogyakarta: Bulan Bintang, 1980

Direktorat Jenderal Pembinaan Kelembagaan Agama Islam, Bahan Penyuluhan Hukum, Jakarta : Departemen Agama RI, 2001

Hadikusuma, Hilman. Hukum Perkawinan Indonesia Menurut Perundangan, Hukum Adat dan Hukum Agama, Bandung: Mandar Maju, 1990

Masykuri, Abdillah. Distorsi Sakralitas Perkawinan Pada Masa Kini dalam Mimbar Hukum No. 36 Tahun IX, 1998

Mohammad, Fauzil, Adhim. Kupinang Engkau dengan Hamdalah, cet. XVIII Yogyakarta : Mitra Pustaka, 2003

Rofiq, Ahmad. Hukum Islam di Indonesia, Jakarta: PT. Raja Grafindo Persada, cet. Ke-4, 2000

Sudarsono. Hukum Perkawinan Nasional , cet. III, Jakarta : Rineka Cipta, 2005

Syarifuddin. Kamus Al Misbah, Jakarta: Bina Aksara, t.t.

Syarifuddin, Amir. Hukum Perkawinan Islam di Indonesia, Antara Figh Munakahat dan Undang-undang Perkawinan, Jakarta: 2006

Undang - undang No. 1 Tahun 1974 Tentang Perkawinan

Kompilasi Hukum Islam (KHI) 